\title{
耐震補強技術（土木）
}

\author{
竹田 哲夫*1 $・$ 山野辺慎一*2
}

1.はじめに

コンクリート構造物に限らず，構造物の補修や補強に ついては, 兵庫県南部地震以降, その必要性から各機関 で精力的に研究が進められ, 種々の工法が開発され, す でに数多くのコンクリート構造物に適用されてきた。

一方で，今後の建設投資は縮小されることが確実であ り, 補強工事に対してもコストの削減が要求されている。 また, 工事に関わる施工・環境条件も, 㛜しさを増して いる。たとえば，新設構造物の場合と異なり，耐震補強 工事は, 通常, 既設構造物を使用しながら施工すること が要求される。そのため, 材料搬入や工期などの面で, さまざまな制約を受けることが多い。

さらに, 土木構造物には, 種々のものがあり, 橋梁を 例によっても, 類似した補強工法が適用可能な 1 本柱形 式の橋脚を有するものだけではない。各種の土木構造物 に対し，一様な補強方法では必ずしも対応できないので ある。そのため, 有効な補強方法がないなどの理由で, 補強されずに残された特殊あるいは大規模構造物が存在 することも事実である。

このように，耐震補強については，その必要性は依然 として高いものの，まだ残された課題も多いのである。

本文では，コンクリート土木構造物の耐震補強技術の 現状として, 各種方法の概要を述べ, 代表的な工法や補 強に関わる個別の技術を紹介し，今後の課題を整理する。

\section{2. 耐震補強工法の分類}

\section{1 而震補強に対する要求性能}

耐震補強に対する要求性能としては, 一般に, 耐力の 向上，じん性の向上，および地震力の低減が挙げられる。

耐力とは特殊な構造物を除けば，一般に曲げ耐力とせ ん断耐力であり，そのどちらか，場合によっては両方の 向上が必要となる。軸方向に引張力を負担するような材 料を部材表面に接着するなどして曲げ耐力を向上させる ことは，比較的容易であるが，実際の施工に拈いては， その両端の定着を確実にする必要がある。また，単に曲 げ耐力を向上させると破壊モードが曲げ破壊からせん断 破壊になる恐れがある。同様に, 補強した部材の耐力を

*1 たけだ・てつお/鹿島建設技術研究所 主席研究員（正会員） ＊2 やまのべ・しんいち／同上 主管研究員（正会員）
向上させた結果，構造全体としての破壊が，他の部材の 脆性的な破壊モードあるいは補修が不可能な部材の破壊 となってしまうこともある。耐力の向上においては，接 合部の耐力や構造全体での耐力のバランスに注意が必要 である。

じん性の向上とは, 地震時の変位や地震後の残留変形 が許される範囲で変形性能を増大させて, 脆性的な破壊 を防止するものである。詳細については後述するが, 鉄 筋コンクリート柱などの軸方向部材において, 部材表面 を補強してコアコンクリートの拘束を高めることにより， 変形性能を向上させるものであり，種々の工法が開発さ れ，多くの実績がある。また，鋼製の柱部材に対しては， 基部にコンクリートを充てんすることで，局部座屈を防 止する方法むある。

地震力の低減とは，地震時の慣性力を低減することで 各部材の断面力を低減するものである。その方法のひと つに, 地震動と構造物の共振を避けるために構造物の固 有周期を伸ばし，減衰を付加する免震化がある。橋梁の 免震化には，上部構造である主桁を特定の橋脚で固定し てその橋脚のみに地震力を負担させるのではなく, 複数 の橋脚にバランスよく地震力を分散して負担させる効果 むある。

実際の耐震補強に扔いては, 上記の要求性能のどれか 一つを向上させることで構造物全体としての耐震性を向 上させることは必ずしも有効ではなく，構造物や施工の 条件に応じて，いくつかを組み合わせることも必要になっ $\tau く る 。$

橋梁を例として, 上記の要求性能を向上させ, 構造物 全体としての耐震性能を向上させることを考えてみる。 どの部材の耐震性を向上させるかによって補強方法を分 類すると, 表-1のようになる。この中から, 設計・施 工の制約条件, 補強効果, コストを考慮し, 必要に応じ て組み合わせて選択している。

\section{2 耐震補強工法の分類}

土木構造物にはさまざまなものがあるため, その耐震 補強にも多数の工法がある。耐震補強の歴史が浅いこと からも, 必ずしも統一した分類はないが, ここでは, 既 往の分類を参考にし，表-2に示すように，部材増厚， 補強材被覆, 補強材挿入, 部材増設, および免震化に分 類した。 
表-1 橋梁の耐震補強法の分類（参考文献 1）に一部追加）

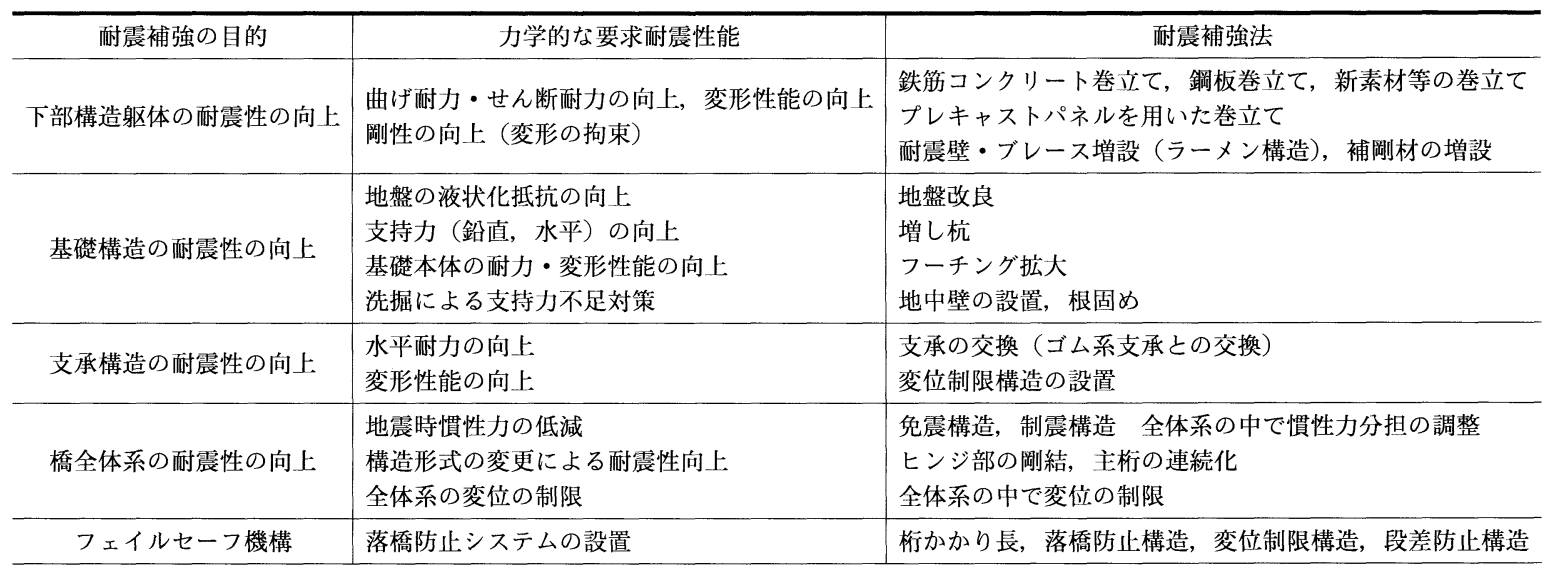

表-2 耐震補強工法の分類（参考文献 2）を一部修正）

\begin{tabular}{|c|c|c|}
\hline 類 & 補強工法 & 補強工法の概要 \\
\hline \multirow{3}{*}{ 部材増厚 } & コンクリート巻立て工法 & $\begin{array}{l}\text { 既設部材に鉄筋または } \mathrm{PC} \text { 鍋材を配置し，コンクリートを打足し，断面を増加させて補強を図る } \\
\text { 工法。比較的大断面の補強を行う場合に適用される。 }\end{array}$ \\
\hline & モルタル吹付け工法 & $\begin{array}{l}\text { 既設部材に帯鉄筋やスパイラル鉄筋等を配置し，モルタルを吹付け一体化することにより補強を } \\
\text { 図る工法。一般に，コンクリート巻立て工法に比べ部材断面の増加を少なくできる。PC 鋼線等 } \\
\text { を用いることも可能である。 }\end{array}$ \\
\hline & プレキャストパネル巻立て工法 & $\begin{array}{l}\text { 内部に帯鉄筋等を配置したプレキャストパネルを柱部材周面に配置し，接合キーにより閉合し， } \\
\text { 柱とパネルの空隙にグラウト材を注入することにより一体化し，補強を図る工法。 }\end{array}$ \\
\hline \multirow{3}{*}{ 補強材被覆 } & 鋼板巻立て工法 & $\begin{array}{l}\text { 既設部材に鋼板を巻き, 鐶板との間に無収縮モルタルやエポキシ樹脂等を充てんして, せん断お } \\
\text { よびじん性補強を行う。曲げ補強も期待する場合には, 部材接合部や基礎に鋼板を定着すること } \\
\text { により可能である。 }\end{array}$ \\
\hline & $\begin{array}{l}\text { FRP (炭素繊維・アラミド繊維) } \\
\text { シート巻付け (接着) 工法 }\end{array}$ & $\begin{array}{l}\text { 炭素織維シートあるいはアラミド緎維シート等を含浸樹脂を用いて部材表面に貼り付けて, 補強 } \\
\text { を図る工法。クレーン等の重機が不用であり, 補強厚さも薄く建築限界等の支障が少ない。 }\end{array}$ \\
\hline & FRP 吹付け工法 & $\begin{array}{l}\text { ガラス繊維等と樹脂をスプレーガンで直接部材表面に吹付けて, 補強を図る工法。補強厚も薄く, } \\
\text { 建築限界等の支障が少ない。スチロールクロス等を併用することにより, 補強効果をさらに向上 } \\
\text { できる。 }\end{array}$ \\
\hline \multirow[t]{2}{*}{ 補強材挿入 } & 鉄筋挿入工法 & $\begin{array}{l}\text { 橋脚等の既設部材を削孔する。鉄筋を挿入し，モルタル等を充てんして躯体断面内に所要鉄筋量 } \\
\text { を追加することにより，せん断補強およびじん性補強を行う。 }\end{array}$ \\
\hline & $\mathrm{PC}$ 鋼棒插入工法 & 上記鉄筋の代わりに PC 鋼棒を扱入する。必要により，プレストレスを導入する。 \\
\hline \multirow{2}{*}{ 部材増設 } & 壁増設 & $\begin{array}{l}\text { ラーメン高架橋等の柱間に壁を増設することにより, 曲げおよびせん断耐力を大幅に増加させる } \\
\text { 工法である。 }\end{array}$ \\
\hline & ブレース増設 & $\begin{array}{l}\text { ラーメン高架橋等の柱間にブレースを増設することにより, 既設柱部材等に作用する地震時水平 } \\
\text { 力を低減させる工法である。 }\end{array}$ \\
\hline \multirow{3}{*}{ 併用工法 } & $\begin{array}{l}\text { コンクリート巻立て工法＋鋼板巻 } \\
\text { 立て工法 }\end{array}$ & $\begin{array}{l}\text { 大断面の橋脚等において, 主として曲げ補強を鉄筋コンクリート巻立て工法により行い，せん断 } \\
\text { およびじん性補強を鋼板巻立て工法に期待する場合など。 }\end{array}$ \\
\hline & $\begin{array}{l}\text { 鉄筋挿入工法＋コンクリート巻立 } \\
\text { て工法 }\end{array}$ & $\begin{array}{l}\text { 大断面の橋脚等において, コンクリートの拘束効果をより高めるため, 鉄筋コンクリート巻立て } \\
\text { 工法に鉄筋挿人工法を併用する場合など。 }\end{array}$ \\
\hline & $\begin{array}{l}\mathrm{PC} \text { 鋼棒挿入工法＋鋼板巻立て工 } \\
\text { 法 }\end{array}$ & $\begin{array}{l}\text { 大断面の橋脚等において, 鋼板巻立て補強工法によるコンクリートの拘束効果を高めるため, } \\
\mathrm{PC} \text { 鋼棒挿入し鋼板をつなぐ場合など。 }\end{array}$ \\
\hline 免震化 & 免震化工法 & 支承構造を有する場合に, 固定・可動支承を反力分散支承や免震支承に取り替える。 \\
\hline
\end{tabular}

部材増厚, 補強材被覆, 補強材挿入およびこれらの併 用工法は，橋脚の躯体や地下トンネルの中柱などに，す でに多くの実績がある。橋脚躯体に比べそれ以外の実施 例は少ない。これは，地上タンクの側壁のように必ずし む耐震に対して厳しくないことも事実であるが，有効な 補強方法がないこと屯ある。つまり，橋脚の躯体のよう に, 耐震上の弱点部があり, その部分的な補強で構造全 体の耐震性を向上させることができないのである。たと えば，杭を補強すればよいことは分かっていても，費用 を考えると有効な工法がないなどの場合がある。

\section{3. 主な耐震補強工法の概要}

\section{1 巻立てエ法による鉄筋コンクリート部材の補強}

橋脚の躯体などの柱状の部材の補強工法には, 表-3 に示す $\mathrm{RC}$ 巻立て工法, 鋼板巻立て工法, 連続㵶維巻立 て工法がある。

$\mathrm{RC}$ 巻立て工法は, 補強厚さが他の工法に比べ厚いも のの，耐力・じん性いずれの向上も可能で，一般に最む 経済的である。

鋼板巻立て工法は補強後の断面増加が $\mathrm{RC}$ 巻立てより も小さく, 施工時間も短いなどの利点があり, 都市内の 
表-3 鉄筋コンクリート柱部材の耐震補強工法の特徴（参考文献 3）を一部修正）

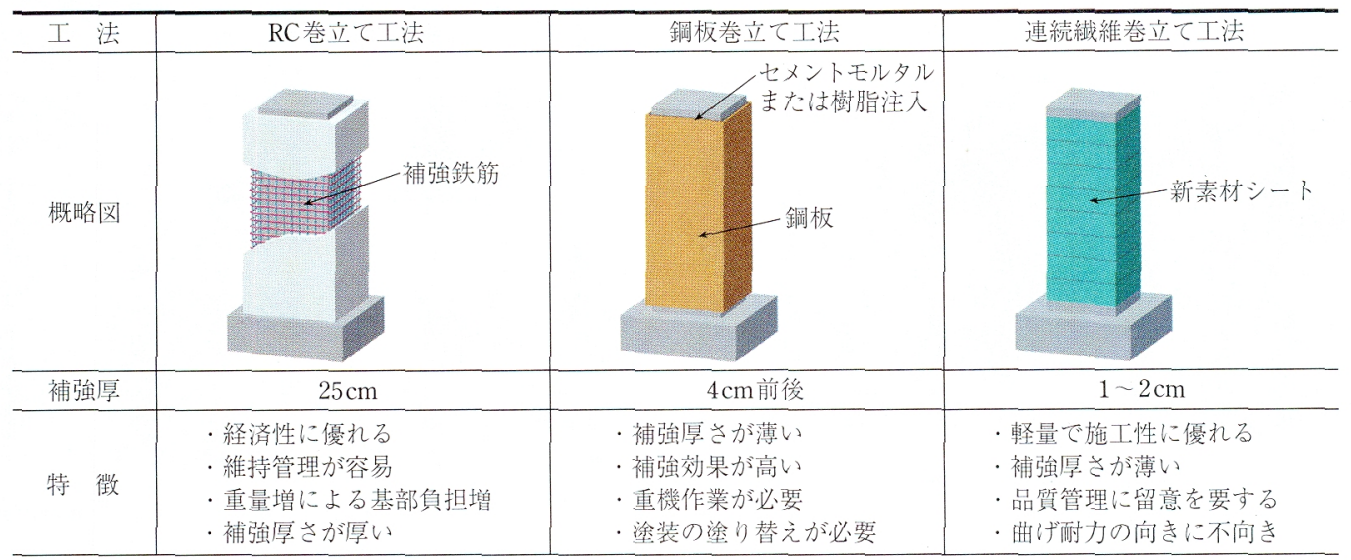

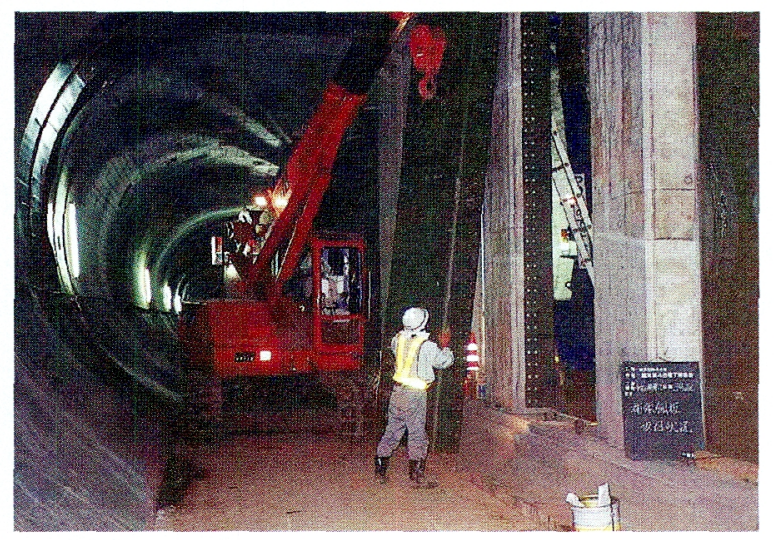

写真-1＼cjkstart鋼板巻立てによるトンネル中柱の施工

橋脚や地下トンネル中柱（写真-1）で数多くの実績があ る。地震時に塑性ヒンジが形成される柱基部に刘しては, 拘束効果の向上と防錆のために，根巻きコンクリートを 施工する場合がある。

連続緘維巻立て工法は，さらに補強厚さが小さく材料 も軽量であることから，施工性に優れている。

\section{2 部材増設による補強}

ラーメン構造の面内方向に対しては，強度と剛性を増 加させる方法として耐震壁やブレースの設置がある。た だし，一般に，固有周期が短くなるために地震時の水平 力が増加し，基礎構造の負担が増えることに留意する必 要がある。

このため，比較的大きな層間変位が生じる場合には， 図-1のように，ブレースを介してエネルギー吸収を図 る制震装置を設置する方法が検討されているいこの方 法によれば，耐力・剛性の増加を調節でき，地震後には 装置の交換のみで復元できる利点がある。

このような構造要素間の相対変位を制震装置のエネル ギー吸収に変換する方法は，斜張橋などでも期待されて (る5)。

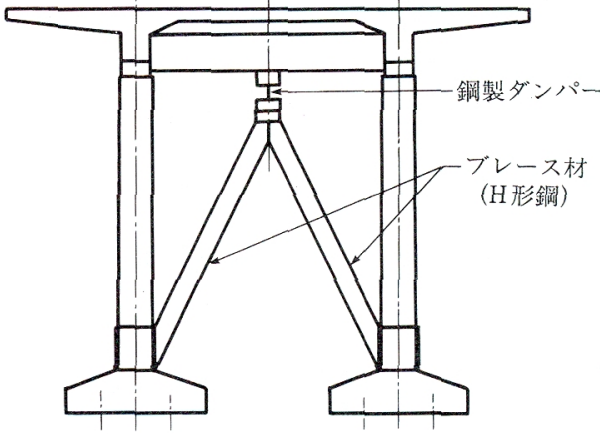

図-1ブレースを介した制震装置の設置方法

4. 最近の耐震補強工法

橋脚躯体の補強方法などの一般的な方法とは異なる比 較的新しい工法として, 水中橋脚の補強方法, 基礎の補 強方法，免震化による耐震補強を以下に紹介する。

\section{1 水中橋脚の耐震補強}

河川内の橋脚などで躯体が水中にある場合は, 仮締切 り工事によりドライアップする必要がある。こうした方 法は，気中と同様の施工が可能なため，安全で確実な施 工が可能であるものの，工費・工期の面で問題が多かっ た。

こうした問題を解決するため，鋼製作業函による仮締 切り工法 ${ }^{6}$, あるいは仮締切りを必要としないプレキャ スト型枠を用いた水中施工法が開発されている。

写真-2 は鋼製作業函による仮締切り工法の例であり， コの字形の作業函 2 個により橋脚を取り囲み, 油压ジャッ キと止水シールにより橋脚をドライアップするものであ る。作業函自身は，バラストタンクで浮上し，曳航でき る。フーチングのコンクリート表面の仕上げ精度にも依 存するが，止水後の漏水はほとんどなく，気中上同様の 作業環境が得られる。河口部の多径間橋梁のように同一 形状で複数の橋脚に対して繰返し使用できること, 現場 での作業期間が短いことなどの利点がある。 


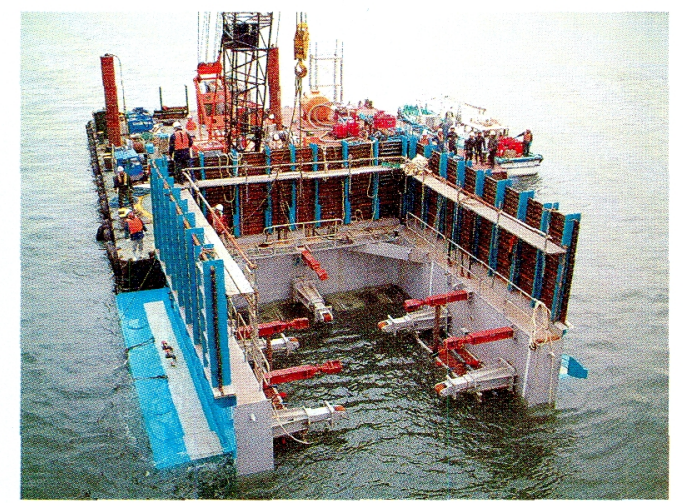

写真-2 据え付け中の鋼製作業函

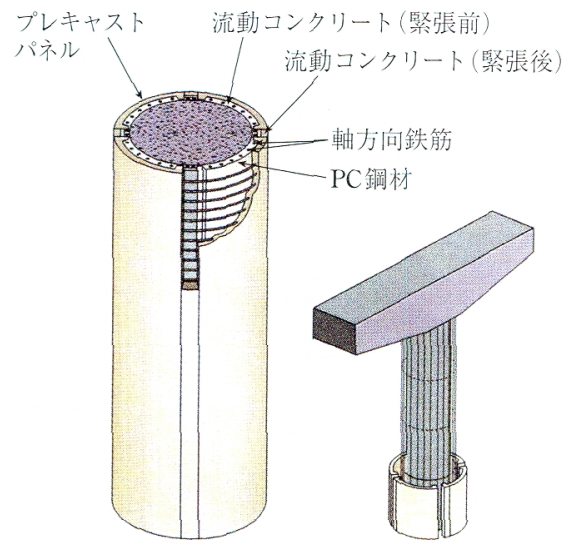

図-2 プレキャスト型枠による橋脚耐震補強の例

一方，プレキャスト型枠を用いた工法として，補強鋼 板または補強鉄筋を組み込んだプレキャス卜型枠を設置 し，既設コンクリートとの隙間にコンクリートまたはモ ルタルを充てんし，一体化をするものがある。プレキャ ス卜型枠同士に，後述の機械的継手を用いる工法もある。 図-2は，プレキャスト型枠を設置し，既設橋脚との隙 間に軸方向鉄筋を配置し，横拘束鉄筋としてポリエチレ ン被覆された PC 鋼材を巻き付け緊張する工法であるっ。 こうしたプレキャスト型枠を用いた工法は, 気中のコン クリート巻立て工法の水中施工への展開として開発され たものであり, 今後の適用が増えるものと思われる。

\section{2 マイクロパイルによる基礎の補強}

基礎の耐震補強工法を, 表-4にまこめた2)。周辺地盤 の改良・補強により支持力を増加させることにより基礎

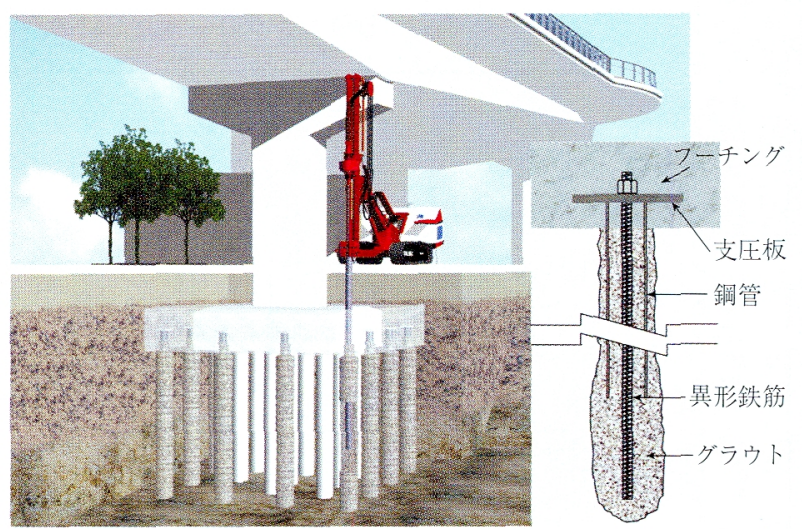

図-3 マイクロパイルによる基礎の補強

の支持力を増加させる方法に比へ，基礎本体の構造的な 補強は, 一般に確実で経済的である。このうち, 増し杭 による基礎の拡張は，橋梁や夕ンク基礎をはじめ多くの 実施例 ${ }^{87,9)}$ がある。

新しい補強工法としては, マイクロパイルによるもの

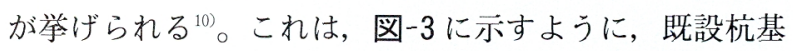
礎の周辺に直径 $300 \mathrm{~mm}$ 以下の小径の杭を多数施工し, 既設フーチングと一体化するむのである。小型のボーリ ングマシンで施工できることから，桁下など作業空間に 制限があっても施工可能であること，また補強材に鋼管 と異形鉄筋を用い高い支持力, 杭耐力が得られるなどの 特長がある。

\section{3 支承の取替えおよび免震化による耐震補強}

河川内の橋脚で河積阻害率の制約を受ける場合や，橋 梁下が虞舗に利用されていて立ち退きの問題がある場合 には, 巻立て工法が適用できない。このような橋脚にお いては, 橋脚自身の耐力やじん性の向上ではなく, 地震 時の慣性力の低減による耐震補強が必要となる。

下部構造に対する地震力を低減する方法としては, 既 存の可動・固定支承を反力分散支承に取り替えることに より, 固定支承有する橋脚に集中していた地震時の水 平力を複数の橋脚・橋台に分散させる方法, あるいは, その際に免震支承を用いて, 長周期化之減衰の付与によ り，地震応答そのものを低減する方法が有効となる。

コンクリート橋に限らず, 支承の取替えや析の連続化 の例は，すでに数多く報告されている ${ }^{11)}$ 。しかしながら，

\section{表-4 基礎構造物の補強工法}

\begin{tabular}{|c|c|c|c|}
\hline 分 & 類 & 法 & 概 \\
\hline \multirow{3}{*}{$\begin{array}{l}\text { 基礎本体の } \\
\text { 構造的補強 }\end{array}$} & 基礎の挔張 & 杭・フーチングの増設 & 新設の杭とフーチング部に荷重を分担させ，基礎の支持力を高める。 \\
\hline & \multirow{2}{*}{$\begin{array}{l}\text { 補強部材の } \\
\text { 設置 }\end{array}$} & $\begin{array}{l}\text { 枠基礎・地下連続壁・ } \\
\text { 連続地中梁による補強 }\end{array}$ & 地下連続壁・連続地中梁に荷重を分担させ, 基礎の支持力を高める。 \\
\hline & & アースアンカー工法 & 橋台などで，アースアンカーに荷重を分担させ，基礎の支持力を高める。 \\
\hline \multirow{4}{*}{$\begin{array}{l}\text { 周辺地盤の } \\
\text { 改良・補強 }\end{array}$} & \multirow[t]{2}{*}{ 支持力強化 } & $\begin{array}{l}\text { 締固め工法 } \\
\text { 地盤固化工法 }\end{array}$ & $\begin{array}{l}\text { 鋼矢板による楴切り工やグラウト注人工により，地盤の支持力・強度を高め } \\
\text { る。基礎周辺に既設埋設物があり増杭の配置が困難な場合などに適する。 }\end{array}$ \\
\hline & & 根固め工法 & 洗掘により支持力の不足した場合に，根固めにより地盤の支持力を高める。 \\
\hline & \multirow{2}{*}{$\begin{array}{l}\text { 間隙水圧低 } \\
\text { 減 }\end{array}$} & 地下水位低下工法 & 粘性土に対し，排水による压力低下を利用して強度を増加する。 \\
\hline & & 間隙水圧消散工法 & 砂質土に対し，地震時の過剩間隙水圧を早期に消散させ液状化を防止する。 \\
\hline
\end{tabular}




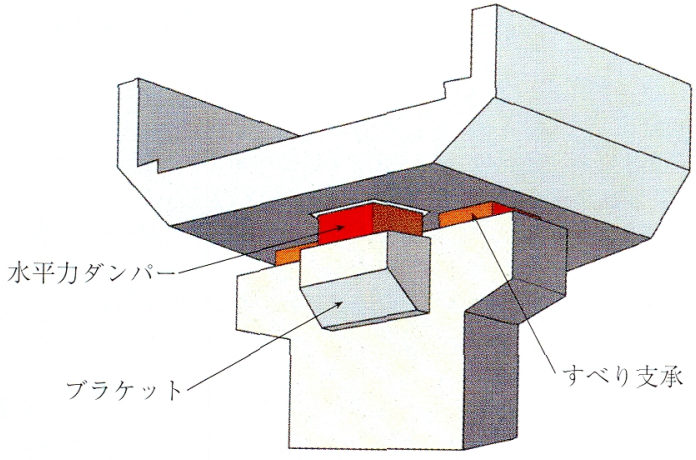

図-4 既設橋梁の免震化工法の概要

コンクリート橋では, 重量が大きく桁の仮受けが容易で はないこと，狭鄎な桁下空間での施工性の問題，旧可動 支承のアンカーボルトの耐力不足, コンクリートのはつ りによる橋脚天端や桁下面の損傷など，施工上の問題や 制約条件屯多い。さらに, 免震支承は通常の支承に比べ 鉛直方向の寸法が大きくなるので，既存の桁下空間に設 置できない場合や，桁端の遊間が少ないために地震時に は伸縮装置の破損や隣接する桁との衝突が起こり, 免震 効果が十分に発揮されない場合がある。

こうしたことから，既設橋梁に対して機能的にも施工 的にも要求を満足する免震化工法として, 既設支承をす べり支承に改造し新たに水平力ダンパーを設置する工法 が開発12)され，すでに20橋以上に適用されている。

本工法の概念図を図-4に示す。本工法における免震 装置は, すべり支承と水平力ダンパーから構成されてい る。免震支承を用いる免震化工法との相違点は, すべり 支承の摩擦減衰上水平力ダンパーの履歴減衰の二重の減 衰付加により，桁变位を抑制し地震力の低減を図ること である。そのため, 中小規模地震による伸縮装置の破損, 橋析の衝突を免れることができ, 橋軸方向だけでなく橋 軸直角方向の免震む可能になる。

\section{5. 耐震補強を支える要素技術と今後の課題}

耐震補強には，計画・調查・設計・施工・維持管理の 各ステップにおいて，さまざまな要素技術が必要となる。

たとえば，耐震補強においては，多くの場合，補強材 料・部材と既設コンクリートを一体化・接合して耐震性 能を向上させるので, 既設コンクリートの表面処理, 削 孔，切断などが必要になる。また，施工に扔いては，す でに述べたように，狭险な場所への資機材の搬入を余儀 なくされ，工期・工事時間帯の制約を受けることから， 施工性のよい材料・工法が求められている。

そのため, 要素技術としての, 新材料, 表面処理工法, 削孔技術，あるいは鉄筋や鎆板の定着・継手工法につい てこれまでに種々のものが開発されてきた。紙面の関 係からすべては紹介できないが，代表的な要素技術をい くつか紹介し，今後の課題をまとめてみる。

コンクリートの表面処理工法としては, ウォータージェッ

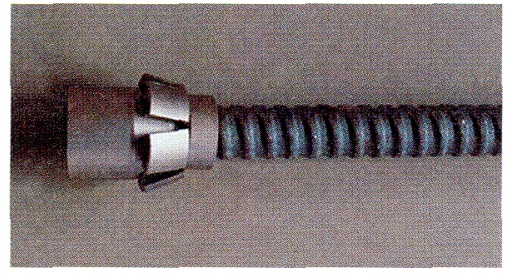

写真-3 新しいアンカー工法

ト工法がある133。ウォータージェット工法とは，直径 $0.1 \sim 2 \mathrm{~mm}$ 程度のノズルから高速で高圧水を噴射する あのである。付着力を確保して新旧コンクリートを一体 化するには，既設コンクリート表面のレイタンスや微細 なひび割れによる数 $\mathrm{mm}$ 厚さの弱層を除去することが 必要であるが，従来のハンドブレーカの打撃では，ひび 割れや骨材の割れが生じるために十分な付着力が得られ ない場合があった。ウォータージェット工法は，施工に おいて騒音と処理水に配慮する必要があるものの, 既設 コンクリートを傷めずに弱層を除去する方法として有効 であり，はつり处理にも適用されている。また，壁式橋 脚などに中間带鉄筋を追加して配置する際の削孔技術に 屯有効であ万う。

既設コンクリートへのアンカー工法としては，金属拡 張アンカーや接着系アンカーが一般的であるが, 補修・ 補強用として改良されたものに, 写真-3に示すものが ある ${ }^{(1)}$ 。これは，アンカー本体に市販のネジ節鉄筋もし くは全ネジボルトを用い，先端に搪張部をつけたむので ある。金属搪張式アンカーに比べ施工時の強い衝撃がな くコンクリートに悪影響を与えない, 接着系アンカーに 比べ定着長が短い，アンカー本体にネジ節鉄筋を用いた 場合には補強鉄筋との継手に機械式継手などの種々の方 法が選択できる，などの利点がある。

また，鋼板巻立て工法においては補強鋼板の接合が必 要になるが，現場溶接に代わるものとして，図-5のよ うな機械的な継手工法が開発されている(1)。これは，鋸 邓状の鋼材のかみ合わせを用いた工法であり，工場製作 した成型鋼板の接続縁を，現場において機械的に接合し て一体化する工法である。無溶接であるため，工期が短 縮でき, 水中での施工も可能である。同様なものに, フ レキャスト型染に扔ける帯鉄筋の継手として，図一6に 示すものがある(1)。

こうした新材料や要素技術についての共通の今後の課 題としては, コストの低減が挙げられる。

また，耐震補強工事は，ケースバイケースとなる場合 が多く，橋脚の躯体などを除けば，一般に標準化するこ とは難しかった。しかしながら，これまでに多少なりと も実施例が增えていることから，マニュアルの改良や実 例集の整備が必要であろう。

一方，これまでに有効な工法がなかった特殊な構造物 や大型構造物に対しては, 今後, 新たな耐震補強技術を 開発する必要があることも忘れてはならない。 


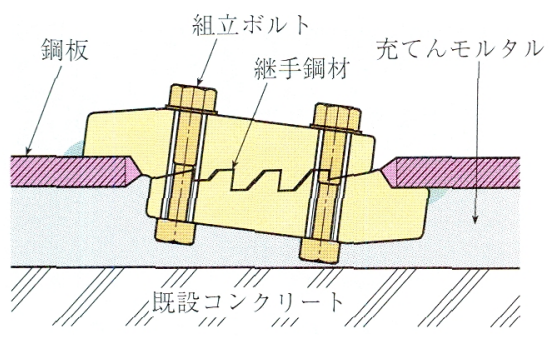

図-5＼cjkstart鋼板巻立てにおける機械式継手

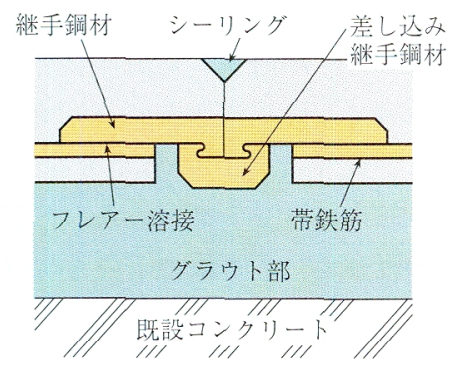

図-6 プレキャスト部材の継手工法

\section{6. おわりに}

コンクリート構造物は社会活動を支える重要な社会資 本であり, その地震による損傷は利用者の生命, 社会・ 経済活動に大きく影響する。特に土木構造物においては, 地震後の救援・復旧活動を脅かすことにもなり，耐震性 を確保することが極めて重要である。さらに今日では， 補強効果だけでなく，景観・環境などの周囲との調和に 対する配慮なども求められている。

こうした要求を満たすのは決してたやすいことではな く，補強に関わる広範な技術が必要となり，依然として， 今後の技術改良や新工法の開発に期待するところが大き い。また，従来型の補強工法や設計法だけでなく，構造 物全体として有効な工法とそれに対応した設計技術が必 要になるものと思われる。
本稿が，耐震補強技術の理解の一助になれば幸いです。

参考文献

1）運上茂樹：道路橋の附震診断・除震補強，基䃈工，Vol. 27, No. 4, pp. 7〜12，1999年 4 月

2）日本コンクリート工学協会：コンクリート構造物の震災復旧・耐 震補強技術之事例, 1998 年 8 月

3）察田賢司・井瀬良則：既設道路橋の耐震補強優先度一日本道路 公団に扔ける事例一，既設構造物の耐震補強に関するシンポジウ 么論文集，pp. 9 13，2002 年11月

4）松本信之・曾我部正道・岡野素之・涌井 一・大内 一：鋼製ダ ンパーブレースを用いた鉄道高架橋の振動性状改善に関する研究, 構造工学論文集. Vol. $46 \mathrm{~A}$, pp. 547 554, 2000 年 3 月

5）土木学会：滅震・免震・制震構造ガイドライン (案)，pp. 63～67, 2002 年 1 月

6）池田省三：水中構造物の検查・補修・補強工法「NDR 工法」, 電 力土木, pp. 121 124, 1997 年 3 月

7）渡辺 寛：PC 巻立て工法による水中橋脚の酎震補強, 土木学会 誌，pp. 50 52，2002 年 12 月

8）石崎 浩・江川典聰：阪神高速道路 5 号線の橋脚基礎の復旧，基 礎工, Vol. 24, No. 9, pp. 39 45，1996 年 9 月

9）広根政義・井門幸人：火力発電所に抢ける眝油多ン基礎杭の被 害と補強, 基砒工, Vol. 24, No. 9, pp. 99 103，1996 年 10 月

10）福井次郎・石田雅博・加藤秀章・三木健男：マイクロパイルによ る橋梁基礎の補強に関する检討, 第 3 回耐震補強・補修技術, 耐 震彰断技術に関するシンポジウム, pp. 87〜 94，1999 年 7月

11）倉成裕之・前田隆志・弓削磯雄：美々津大橋における支承取替元 工事報告, 構造物の診断之補修に関する第 9 回技術・研究発表会 論文集，日本構造物診断技術協会，pp. 36 43, 1997 年 10 月

12）日紫喜剛啓・広中良和：免震化工法による既設橋梁の捄震補強, 橋梁と地下構造物の免震・制震講㱠会テキスト, 土木学会, pp. $149 \sim 156,1999$ 年 5 月

13）紫桃孝一郎・上東 泰・野島昭二・吉田 敦：ウォータージェッ 卜技術を利用した新旧コンクリート構造物の一体化処理，コンク リート工学，Vol. 38，No. 8，pp. 40 54，2000 年 8 月

14）吉田健太郎・古市耕輔・山中宏之・須藤 豊：拡底式あ之施工了 ンカーの引張耐力と疲労特性に関する確認試験, 土木学会第 56 回年次学術講演会講演概要集，pp. 1194 1195，2001年 10 月

15）前田敏也・近藤正佳・鈴木東四郎 - 今并克美・羽㴊貴士：水中部 $\mathrm{RC}$ 橋脚の耐震補強工法の開発, 第 3 回耐震補強・補修技術, 而 震骖断に関するシンポジウム講演論文集，pp. 17〜24，1996 年 7 月

16）小原孝之・鈴木顕彰・中原勝一・知念正尚： $\mathrm{RC}$ 橋脚の水中柎震 補強工法の開発と施工, 第 4 回耐震補強 - 補修技術, 而震款断技 術に関するシンポジウム，pp.9〜16，2000 年 7 月 